\title{
It's Online, It's News: Appropriation Of Viral Narratives By The Digital Press
}

\author{
Ana Martins \\ CIAC \\ Universidade do Algarve, \\ Portugal \\ fcerolm@ualg.pt \\ Olivia Novoa Fernández \\ CIAC \\ Universidade do Algarve, \\ Portugal \\ onfernandez@ualg.pt
}

\author{
Ignacio Aguaded \\ Universidad de Huelva \\ Espanha \\ ignacio@aguaded.es
}

\author{
Mirian Tavares \\ CIAC \\ Universidade do Algarve, \\ Portugal \\ miriantavar@gmail.com
}

\begin{abstract}
At the crossway between information and entertainment, memes and newsgames are some of the news formats which, made viral in social networks, complement the informational experience and compete with the traditional news media in constructing alternative readings of the real. If in the light of Bakhtin (2002), journalism can be understood as a secondary discursive genre that feeds on primary genres (pp. 61-62), how is one to understand the circulation of these discourses produced from journalistic events in social networks? On the other hand, how are these narratives appropriated by the media? What functions do they play in media discourse? In this article we present some examples of products created from events of political impact. Thereafter, we discuss, by the analysis of a set of news stories, how the digital press, in the Iberian context, makes use of them. The purpose of this article is to contribute to the reflection on how the news media relate to these new narratives.
\end{abstract}

\section{KEYWORDS}

Journalism; viral narratives; social networks; infotainment; political satire

\section{1 | INTRODUCTION}

The interdependence between the media and the societies in which they are developed, and the dynamics established in domains such as the notion of truth and the valorization of knowledge, have been discussed by several thinkers and researchers from quite different theoretical, and even ideological, contexts. Postman (2006) suggested that the media are, to a certain extent, implicated in our epistemologies, because the character of each medium conveying information ultimately determines our definitions of truth (p. 44). Also, by falling outside its narrowest scope of use, each medium of communication ends up encompassing individual and collective experiences of the world and of social institutions, determining our perceptions and conceptions (p. 45). Postman holds that "a major new medium changes the structure of discourse; it does so by encouraging certain uses of the intellect, by favoring certain definitions of intelligence and wisdom, and by demanding a certain kind of contentin a phrase, by creating new forms of truth-telling" ( $p$. 57). From another point of view, scholars like Rosen (2000), Zelizer (2004) and Kovach \& Rosenstiel (2014), among others, underline the idea that the legitimacy of journalism emanates from its ability to produce a presentation of the world, independently of other social fields, helping communities to, as Jarvis states (2013), "organize their knowledge so they can better organize themselves", aiming at strengthening democracy. This legitimacy is based on a relation with reality, truth and facts, of which the media presents themselves as vehicles, which has guided the conventions, standards and practices of current 
journalism, even though it may be under questioning in recent times (Zelizer, 2004; Rosen, 2000). Throughout the 20th century, mass media, the "most glaring superficial manifestation" of the societies of the spectacle, as Debord put it (1977, p. 79), created new forms and discourses related to the truth, setting the stage for a hybrid genre that has recently taken over the public space: infotainment. This approach between information and entertainment, the result of the blurring of boundaries between what would be the labor of seeking, treating and disclosing the truth and what would be outside that domain, has been made, as we know, on account of a relinquishing of journalism to commercial criteria. Some of the main consequences of this infotainment regime are described, and are constantly experienced, for example, in the exercise of citizenship (Brants, 2005, p. 41 , among others). On the other hand, in the same logic of amusement, some formats appeared that proposed alternative forms of access to the present. In a study on satirical infotainment in Turkey, Eşitti and Işık (2004) argue that the academy tends to underline the negative aspect of infotainment and to neglect the potential of satiric infotainment news ( $p$. 271). The authors claim that through humor, satire has the power to influence political attitudes - and that it can even attract depoliticized publics, or people with little interest in hard news and political affairs, performing a democratizing effect. That is even more evident in the online media, where "satiric infotainment gives people the chance to escape the screening of the gatekeepers of the traditional media" (p. 272), with all its good and negative outcomes, as is widely perceived. In fact, the 21 st century has brought transformations into the so-called traditional media and, once again, it is possible to see how these transformations end up affecting the concept of truth. In this article, we discuss some of the new trends in which the digital press emulates narrative forms promoted by the Internet, in the context of politainment, a concept used to designate the mixture between political information and entertainment, with greater or lesser weight of each of the ingredients (Berrocal, Campos-Domínguez \& Redondo, 2013, among others). The presented set of news stories aims to illustrate different ways in which Portuguese and Spanish online newspapers dig around social networks and how they replicate different types of viral contents, such as newsgames and memes.

\section{2 | SPECTACLE, INFORMATION AND POLITICAL SATIRE}

According to Abril (2005), the relationship between entertainment and information is part of the very essence of the mass media, and it is in the origins of popular newspapers, collected and absorbed from popular literary genres. In this path, the extinct newsreels generated a mixture of information and entertainment that eventually extended from cinema to television. Born from the cinematographic impulse, from the building of the film industry, and from a strategy of fixing audiences in movie theatres, newsreels were a product of showbusiness more than that of journalism (Pontecorvo, 1983, p. 6). Being both shows of curiosities and privileged instruments of propaganda, newsreels were not seen as the main sources of information (Baechlin \& Muller-Strauss, 1952 , p. 63), nor by the public, nor even by their producers, but they were attractive and sensational complements, so to speak, to traditional media. And yet, they left an informational footprint that relates them to the transformation of discourses about truth and truthfulness. Television, in a way that seems even more obvious nowadays, received this legacy and did not fail to pass it on to other media.

Infotainment had, and for the time still has, its biggest expression in television. One of the ways such expression manifests itself is in the treatment of politics, either in news broadcasts, talk shows or satirical shows. Beyond infotainment, as Collins and Riegert (2016) state, the concept of politainment comprehends the uses of political issues in the entertainment industry, and in how politicians manage their campaigns and popularity. Blumler and Kavanagh (1999) discuss the multiplication of channels and media for political communication and the challenges they pose to politicians, journalists and the public (p. 213). For the authors, this third age of political communication, marked by the increasing weight of political communication agents, is also an age of discredit in politicians and their strategies, due to a greater scrutiny by the media (p. 217), and an age of growing populisms, which result both from the proliferation of channels and media, from the failure of ideology, from the increasing importance of marketing, and from the erosion of the media's own status at the public's perspective (p. 220).

This correlation between information and entertainment has gained a tremendous boost with 
new media and the emergence of the Web 2.0. Newsgames, videogames based on news events that can be created with a more or less critical intent, are good examples of this tendency. Newsgames take part in the evolution and profusion of news formats, especially in the context of web journalism. Conceived to be available in multiple devices and platforms, these new audiovisual journalistic narratives aim to maintain and captivate new audiences (Bourscheid, 2017, p. 152). Yet, like what was observed with newsreels, Romero-Rodríguez and Torres-Toukoumidis (2018) point out that:

Newsgames are narrative strategies parallel to the event, so under no circumstances can they be understood as main tools to be informed. Under this advising, the newsgame can be seen as a mixed genre, hypermediated, interactive, auxiliary and correlated with information, but in no case can it be seen as a main journalistic genre (such as news, interview, the review, among others). (p. 46).

In addition to interactive infographics, timelines and other new multimedia and transmedia resources, for the researchers newsgames are supplements with the aim of highlighting some information and enriching the main narrative (p. 46). A Portuguese example, already on the margins of what is considered a classic newsgame, as a serious game, is presented as follows:

This is a fun game about the story of a lawyer who wants to free his favorite prisoner. Everywhere, lawyers use every method at their disposal to free their clients when detained. In this case, the lawyer will have to deliver a sequence of Habeas Corpus to have access to the key that can release the prisoner, having then to give him the key surpassing the judge who will do everything to prevent it from happening. Help the lawyer release his prisoner in the shortest time possible, not forgetting to deal with the journalist who tries to cover the news. (Mobape, 2015; Vamos ajudar "Socras" a fugir da prisão?, 2015).

Socras Escape - O Jogo, on the arrest of former Portuguese prime minister José Sócrates, deserved coverage in several Portuguese online media. Another Spanish example proposes a fight between politicians. Its creator describes it thus:
Play with your favorite politicians and unleash your anger with the opposition! Nobody can stop you in your run to the presidency of the government. You do not need covenants or bosh, you destroy your political enemies to the brink. Punches, wizardry, and the main political figures of Spain in the most characteristic scenarios during the crisis. (Salas, 2016).

In any case, newsgames are usually considered in the category of serious games. With a more critical purpose, in 2004, the Newsgaming.com project presented itself as a team of developers who believed that video games are not just fun, and could lead people to think about the events of the world (newsgmaing.com, n.d.). In the video game Play Madrid (about the $11 \mathrm{M}$ attacks), the player has to click on the candles of the people to make the flame stronger: if he stops clicking, he loses. Bogost, Ferrari, and Schweizer (2010) describe several examples and broadly categorize the concept, including interactive infographics in it. The authors' perspective is very optimistic as to what newsgames - heirs of graphic humor in the press, for their humorous and caricatured content - could contribute to journalism in the digital era. Nevertheless, Gómez García and Cabeza San Deogracias (2016) conclude that the most decisive factor for success of newsgames is that they are associated with a strategy of viral self-promotion of content. For Romero-Rodríguez and Torres-Toukoumidis (2018), in a "supersaturated ecosystem, in constant mediamorphosis, organizations and media companies compete in terms of attracting audiences" (p. 50). According to the authors, the "conventional model of offering 'flat' information is ostracized, since content consumption habits have mutated into interactivity and transmedia narrative" (p. 50).

"Word-of-mouth" messaging has become much more powerful with the proliferation of social networks, which facilitate conversations and accelerate the spread of information. Tobin and Braziel (2008, p. 29) define viral marketing as a campaign so compelling that people share it in such a way that it expands like a virus; intentionally or not, people help to sell the product. Among the characteristics of the viral contents that Tobin and Braziel (2008) point out is the fact that they are easy to share, without great loss of time and work by the consumer, are fun and attractive, and have a great exchange value. The context of the viral content is that of the prosumer, a 
concept that was defined by Toffler (1984) in the Third wave, and which is widely used to define this new feature of an Internet audience which, besides consuming, also produces content. In the spectrum of politainment, Berrocal, Campos-Domínguez and Redondo (2013) underline that the actual prosumer takes little action in producing videos, for instance, practicing much more what the authors call "transmediation", that is, "taking messages from 'old media' like television and transforming the message with slight alteration - text, visuals, sound - to adapt to the 'new media', YouTube, by adding a new title, a subtitle or a description" (p. 66). In their study of the Spanish case, the researchers note a certain passivity and describe the politainment prosumer's action as being very limited, both in terms of participation, and in the contents and formats he shares (p. 70).

Starting from Richard Dawkings, in 2008 Tobin and Braziel defined memes as a unit of cultural information which is transmitted virally. Today, memes have acquired a new meaning, perhaps difficult to define, which designates the images of current events manipulated to become satires of the event. A simple definition would be graphic jokes shared on social networks. In the specific case of political content, memes can have various functions, from propaganda purposes to social criticism and political satire, sometimes self-referential. Portuguese Facebook memes pages such as Decomposição de Classe - Humans of late Geringonça, Senhora cá de Casa Okupada or Memes Comunistas para Jovens Marxistas, more or less directly affiliated with political parties, are examples of the political uses of memes. In general, memes lack of informative quality, but they are often originated in an informative event. Of course, within all the memes in circulation, some spread false news. Twitter and WhatsApp are their preferred vehicles. Ultimately, memes respond to the characteristics of viral content because they are easy to share and fun. Souza and Aragão (2016) discuss the ways in which memes are appropriated by journalism in the Brazilian context. They explain that the impact of events on the Internet has become newsworthy and, in a context in which entertainment has itself news value, memes are appealing journalistic products ( $p$. 5). Thus, memes will have the possibility of being object of news the more repercussion they have had and the more unexpected they are. After all, these are not so new criteria in journalism. On the other hand, according to Souza and Aragão, it is interesting to observe how journalism started by treating these contents as a novelty, presenting and explaining them, often in technology-related sections (p. 6). Eventually, like other Internet fait divers, memes ended up gaining space in other sections of the newspapers.

\section{3 | THE VIRAL REACHES THE PRESS: HOW TO HANDLE IT?}

Newsgames, memes, and other narratives of entertainment are regularly the subject of news, especially in online media. Journalism can be understood, as noted by Ponte (2004, pp. 15-16) following Bakhtin (2002, pp. 61-62), as a secondary discursive genre that feeds on primary genres. But could we classify a WhatsApp conversation, for example, as a primary genre? And, if so, which functions do these primary genres perform in media discourse? What happens when journalism embraces those narratives, and what consequences do they have on our readings of the world? From the reading and analysis of Portuguese and Spanish newspapers online, we have selected a set of articles through which we can propose, as a first approach to these questions, a categorization of the roles these narrative forms can play in online journalism.

\section{1 | INTERACTIVE INFOGRAPHICS}

In line with newsgames, interactive infographics are examples of the new reading experience that digital newspapers offer. Beyond more classical infographics, some come close to graphic humor and amusement, as if the reader were playing a game. We may find an example in the Spanish newspaper El Mundo. A simulator of the motion of censure presented in 2018 by Pedro Sánchez, current prime minister of Spain, against former PM Mariano Rajoy, invites us to play the role of a deputy. As we vote or change our vote, the caricatures of the representatives of the Spanish hemicycle also change (Medina, Ricardo \& Barriocanal, 2018).

\section{2 | SOCIAL NETWORKS OF MESSAGES}

Two other examples account for the tendency to use attractive presentations, in this case closer to the everyday communications of the reader, taken as new primary genres, that are emerging from immediate online communicative experience. The first case, another news story from the Spanish newspaper Público about the motion of censure in 
Spain, presents a selection of public statements by Mariano Rajoy and Pedro Sánchez by replicating a conversation through a mobile messaging app (EFE, 2018). The second case, about Brazilian elections, goes beyond recreation, since the facts themselves give the tone for the selected form of presentation. In this news story, El País quite elaborately simulates a WhatsApp group to report on the propaganda in the Brazilian presidential elections (Gonsálves et al., n.d.). Another relevant aspect of this article is that it is developed under the El País Lab, the platform of the Spanish newspaper developed to create digital journalism projects.

\section{3 | MEMES AS NEWS PEGS}

The news story "The memes of two survivors named Mariano Rajoy and Pedro Sánchez" is located in the section Comparte (Share) of Fcinco, the web portal dedicated to young people of the Spanish newspaper El Mundo, which collects news and viral content from the network. The article begins:

You got the WhatsApp group the classic "Rajoy left the group?" Of course. The victory of Pedro Sánchez in the censure motion against the former president of the Government has unleashed all kinds of memes on social networks and messaging services. (FCinco, 2018)

The whole tone of the article is soft but in the text a hyperlink leads to the El Mundo hard news about the motion of censure presented against the Spanish government: "Pedro Sánchez, president of the Government after triumphing the motion of censure against Rajoy" (Cruz, 2018). The logic of hypertext opens the way for the target audience of this section to follow the link and get interested in the reported facts.

"'Censorship memotion': the most commented on the networks" (Cantó, Llanos Martínez, \& Sánchez Hidalgo, 2018) is published in a section of the newspaper El País called Verne, dedicated to Internet content. In fact, Verne even has a specific section dedicated to memes. At the end of the text, the tab "Since you're here" links to other news. These are clearly news stories produced from viral content, used as bait especially for harder-to-reach audiences, such as younger people, in an attempt to get closer to their social media discourse and, of course, to obtain more clicks and get more revenue from advertising. None of this is new, since the press, especially the tabloids, has always made use of appealing headlines.

Two other Portuguese headlines exemplify the use of memes as hooks: "António Costa goes to Twitter and the Internet does not forgive" (2018) and "Costa in jeans caught by surprise by the Angolan reception" (2018). The first one heads an article published in Jornal de Notícias on a controversy generated around a tweet published by the Portuguese prime minister during a fire in Monchique in 2018. Regarding the second article, published in Portuguese Público online, the appearance of António Costa wearing jeans in the reception to his visit to Angola gave rise to several memes. Identified with the tag Diplomacy, the article does not present the memes nor does it develop the episode of its propagation, but the strategy used was to begin by approaching the subject.

\section{4 | ARE VIRAL CONTENTS THE NEWS VENDORS $2.0 ?$}

Meditsch (2002) discusses journalism as a form of knowledge, and the perspective that because it reproduces rather than simply transmitting knowledge it plays a role in the process of social cognition (p. 11). The researcher notices that "different kinds of discourse will approach reality in different ways, defining different truths, each pertinent to an objective or situation" (p. 12). Ultimately, journalism is a mode of knowledge fixed in the immediacy and conditioned by the context of its production, both historically and culturally, and by the manner in which it is produced (pp. 14-18). But, as Meditsch points out, these conditions remain obscure to the public (p.18). "The news is presented to the public as the reality and even if the public perceives that it is only a version of reality, it will be difficult to have access to the decision criteria" (p.19). As far as we are concerned, the attribution of newsworthiness to viral contents is the result of a commercial strategy, and that is not always understood by the public, which ends up naturalizing these topics, narratives, and ways of perceiving the world. If the fight for sales already existed for print newspapers, we may evoke the figure of the newspaper vendor which appears on the cover of Newsgames. Journalism at Play (Bogost, Ferrari and Schweizer, 2010). Capturing audiences in the digital press involves the use of tools such as clickbaits. These strategies have been the subject of criticism: for instance, in a study on those used by the 
newspaper El País, Palau-Sampio (2016) concludes that there has been a profusion of the typical features of the tabloid press, namely the inclination for news that give preference to the curious and the anecdotal, the use of appealing headlines, the scarcity or absence of sources, etc. This illustrates well the perverse effect that predominantly commercial criteria may have on the quality of news production. News media are one of the vehicles through which these viral narratives penetrate our vocabulary, and, consequently, influence the ways we relate to news, what we consider to be valid, true, and fair, what we mock, what we demand or no longer demand from politicians and institutions, and, ultimately, how we participate or no longer participate in our societies as citizens. As Blumler and Kavanagh (1999) already defended in the late 1990s, this is no longer time for paternalisms and "communicators who wish to inform, persuade, or simply keep the attention of their auditors must therefore adapt more closely than in the past to what ordinary people find interesting, engaging, relevant, and accessible" (p. 220). Journalism is certainly a result of its context, and it cannot be alien to it. But journalism cannot lose sight of what distinguishes it from these alternative narrative forms, in their superficial formulas, of easy consumption, otherwise running the risk of becoming, in a future media sphere, a marginal narrative.

\section{5 | CONCLUSION}

We conceive the narratives of the news stories given as examples as viral narratives, not only in the sense in which they are actually viralized, or shared outside the scope of the news media, but as new genres, which adopt, absorb, represent and profit from the characteristics of the viral contents that circulates throughout the social networks. Taking advantage of new digital resources, these formulas, many developed in the media labs of newspapers, perform at least three interconnected functions. In some cases, they serve only as bait for promotion and advertisement strategies, or to reach wider audiences; sometimes their aim is to provide a more appealing presentation of the current events, closer to the environments to which the readers are daily connected, given the expansion of applications like WhatsApp; in events of social and political relevance its task is to recreate the event, as in the last example presented about the Brazilian electoral campaign by WhatsApp, or, on the other hand, to provide an explanatory and/or illustrative complement to the reported facts. Just as the traditional and popular genres of the press and audiovisual media have been an object of academic study, we consider that these viral narratives that journalism incorporates deserve our consideration and require, as Reia-Baptista (2001) would affirm, new literacies.

\section{REFERENCES}

Abril, G. (2005). Teoría general de la información. Datos, relatos y ritos. Madrid: Cátedra.

Antonio Costa vai ao Twitter e a Internet não perdoa. (2018, August 7). Jornal de Notícias. Retrieved from https://bit.ly/2W3SuVH

Baechlin, P., \& Muller-Strauss, M. (1952). Newsreels across the world [PDF]. Paris: UNESCO. Retrieved from https://bit.ly/2KdlgQn

Bakhtin, M. M. (2002). Speech genres and other late essays. University of Texas Press.

Berrocal, S., Campos-Domínguez, E., \& Redondo, M. (2014). Media prosumers in political communication: politainment on YouTube. Comunicar, 43, 65-72. https://doi.org/10.3916/C43-2014-06

Blumler, J. G., \& Kavanagh, D. (1999). The third age of political communication: influences and features. Political Communication, 16(3), 209-230. https://doi.org/10.1080/105846099198596

Bogost, I., Ferrari, S., \& Schweizer, B. (2010). Newsgames. Journalism at play. The MIT Press: London.

Bourscheid, A. P. (2017). Jogando a notícia: narrativas jornalísticas produzidas a partir dos recursos dos games. Pauta Geral-Estudos em Jornalismo, 4(2), 151-166. Retrieved from https://bit.ly/2Z21aOz

Brants, K. (2005). Quem tem medo do infotainment? Media \& Jornalismo, 7, 39-58.

Cantó, P., Llanos Martínez H., Sánchez Hidalgo, E. (2018, June 1). 'Memeción de censura': lo más comentado en las redes. Verne. El País. Retrieved https://bit.ly/2Wxnim1

Collins, S., \& Riegert, K. (2016). Politainment. In G. Mazzoleni (Ed.), The international encyclopedia of political communication (pp. 974-984), Oxford: Wiley Blackwell.

https://doi.org/10.1002/9781118541555.wbiepc157 
Costa, de jeans, apanhado de surpresa pela recepção angolana. (2018, Setember 17). Público. Retrieved from https://bit.ly/2YUTOfy

Cruz, M. (2018, June 1). Pedro Sánchez, presidente del Gobierno tras triunfar la moción de censura contra Rajoy. El Mundo. Retrieved from https://bit.ly/2KetnO0

Debord, G. (1977). Society of the spectacle. Bread and Circuses Publishing.

EFE. (2018, May 31). "Se lo van a tener que comer con patatas" y otras frases de Rajoy, Sánchez y Ábalos. Público. Retrieved from https://bit.ly/2EKmYq0

Eşitti, Ş., \& Işık, M. (2004). Satiric infotainment as a new type of critical journalism: in the case of turkish website Zaytung. Proceedings of 12th International Communication in Millennium Symposium: $A$ Dialogue Between Communication Scholars, Turkey, 12, 258-273. Retrieved from https://bit.ly/2QwS0X4

FCinco. (2018, June 1). Los memes de dos supervivientes llamados Mariano Rajoy y Pedro Sánchez. El Mundo. Retrieved from https://bit.ly/2W23jYk

Gómez García, S., \& Cabeza San Deogracias, J. (2016). The informative speech of newsgames: the "Bárcenas case" on games developed for mobile devices. Cuadernos.info, 38, 137-148. https://doi.org/10.7764/cdi.38.593

Gonsálves, P., Ser, G., Oliveira, J., Rodríguez, P., Hernández, F., Fernández, A., \& Lin, L. (n.d.). Los 'whatsapps' de una campaña envenenada. El País. Retrieved from https://bit.ly/2Pu8e $5 \mathrm{~g}$

Jarvis, J. (2013, June 30). There are no journalists [Blog post]. Retrieved from https://bit.ly/2KfvFwa

Kovach \& Rosenstiel (2014). The elements of journalism. What newspeople should know and the public should expect. New York: Three Rivers Press.

Medina, P., Ricardo, \& Barriocanal, J. (2018, May 29). Simulador de la moción de censura de Pedro Sánchez. El Mundo. Retrieved from https://bit.ly/2WyNSv9

Meditsch, E. (2002). O jornalismo é uma forma de conhecimento? Media \& Jornalismo, 1(1), 9-22.
Mobape. (2015). Socras escape - O jogo [Mobile application software]. Retrieved from https://www.apple.com/itunes/

Newsgaming.com (n.d.). Retrieved from http://newsgaming.com/people.htm

Palau-Sampio, D. (2016). Metamorfosis de la prensa de referencia en el contexto digital: clickbait y estrategias de tabloide en Elpais.com. Comunication \& Society, 29(2), 63-80. Retrieved from https://bit.ly/2Wwpf2h

Ponte, C. (2004). Leituras das notícias. Contributos para uma análise do discurso jornalístico. Lisboa: Livros Horizonte.

Pontecorvo, L. (1983). What is newsreel? In J. Ballantyne (Ed.), Researcher's guide to British newsree/s. London: British Universities \& Video Council.

Postman, N. (2006). Amusing ourselves to death: public discourse in the age of showbusiness. New York: Penguin Books.

Reia-Baptista, V. (2011). Os media, as literacias e a cidadania. In S. Pereira (Ed.), Literacia, media e cidadania. Actas do $1 .^{\circ}$ Congresso Nacional (pp. 4958). Braga: Centro de Estudos da Comunicação e Sociedade, Universidade do Minho. Recuperado de https://bit.ly/30Tk1No

Romero-Rodríguez, L., \& Torres-Toukoumidis, A., (2018). Con la información sí se juega: los newsgames como narrativas inmersivas transmedias. In A. Torres-Toukoumidis \& L. RomeroRodríguez, Gamificación en Iberoamérica. Experiencias desde la comunicación y la educación (pp. 35-53). Retrieved from https://bit.ly/2TLCK8O

Rosen (2000). Para além da objetividade. Revista de Comunicação e Linguagens. Jornalismo 2000, 27, 139-150.

Salas, J.G. (2016). Spanish political fight [Mobile application software]. Retrieved from https://apple.co/2QDbAkz

Souza, I., \& Aragão, R. M. (2016). Onde a zoeira encontra seu limite: uma análise do uso de memes no jornalismo do Estadão. Proceedings of XVIII Congresso de Ciências da Comunicação na Região Nordeste Caruaru PE, Brasil. Retrieved from https://bit.ly/2EL6KgB 
CITAR Journal, Volume 11, No. 1 - Thematic Dossier: Marginalized Narratives

Tobin, J., \& Braziel, L. (2008). Social media is a cocktail party. Why you already know the rules of social media marketing. North Carolina: Ignate Social Media.

Toffler, A. (1984). A terceira vaga. Lisboa: Livros do Brasil.

Vamos ajudar "Socras" a fugir da prisão? (2015, May 22). Diário de Notícias. Retrieved from https://bit.ly/2WxXer0

Zelizer, B. (2004). When facts, truth, and reality are god terms: on journalism's uneasy place in cultural studies. Communication and Critical/Cultural Studies, 1(1), 100-119.

https://doi.org/10.1080/1479142042000180953 